\title{
Fish fauna of Wajoo nullah, an important tributary of the river Ravi in Kathua District, Jammu Region, Jammu and Kashmir State, India
}

\author{
S.P.S. Dutta \\ Emeritus Fellow (UGC), Department of Environmental Sciences, University of Jammu, Jammu (J\&K), INDIA \\ E- mail: duttasps@gmail.com
}

Received: April 29, 2016; Revised received: June, 1, 2016; Accepted: June 10, 2016

Abstracts: Ichthtyofaunistic survey in perennial Wajoo nullah,an important tribitry of river Ravi in Kathua District, has shown the existence of 64 fish species belonging to 7 orders, 17 families and 42genera. Gudusia chapra and Parambassis bacails are the new records for Jammu and Kashmir State. Fish fauna is dominated by Cyprinifonnes (37 species), followed by Siluriformes (12 species), Perciformes (9 species), Synbranchiformes and Osteoglossiformes ( 2 species each) and Clupeiformes and Beloniformes (1 species each). Overexploitation, illegal fishing and fishing during breeding season are serious threats to fish resources in Wajoo nullah.

Keywords: Fish fauna, Wajoo nullah, tributary, the river Ravi, Kathua district

\section{INTRODUCTION}

Kathua district of Jammu region is drained by the river Ravi and is joined by a large number of seasonal and perennial tributaries. Some of these tributaries at the foot hills of Shivaliks are spring fed, pooled, highly productive water bodies having a rich diversity and density of macrophytes, algae, macrobenthos, prawns, crabs, fish etc. Due to good water quality and rich diversity of fish food organisms many fish species from the river Ravi migrate freely for breeding and feeding and contribute to the rich fish diversity in the area Earlier, Joshi et al (1978). Dutta and Kour (2006) Dutta et $a l$, (2006) and Rathore and Dutta (2015ab) have added to the study of fish fauna of Kathua District. There is no record of fish fauna of Buzhoo nullah and has been enlisted. The objective of the present study is to provide a baseline data to the state fishery department to explore the possibilities of exploiting these water bodies for aquaculture, in framing a proper policy before issuing licenses to the fishermen and in stocking exotic and other fish species in the area.

Topography: Wajoo nullah an important tributary in Kathua district has its origin in village Samper Sola, Kathua town, from a spring. It is mainly spring fed, pooled, sluggish water body and is also joined by a large number of seasonal and perennial tributaries including a distributary of Ujh river. Wajoo nullah enters Punjab down stream Janial village in Kathua and finally enters the river Ravi draining eastern boundary of Jammu region. Its catchment area has vast agricultural fields and overflowing water used for irrigation enters the nullah along its length. There is a good diversity and density of macrophytes and algal blooms are common during certain months.

ISSN : 0974-9411 (Print), $2231-5209$ (Online) All Rights Reserved @ Applied and Natural Science Foundation www.ansfoundation.org

\section{MATERIALS AND METHODS}

Fishes collected by fishermen with castnet were purchased, studied for colour pattern and identified in the laboratory (Hamilton, 1822; Mishra, 1962; Dutta and Maihotra, 1984; Talwar and Jhingran, 1991; Day, 1994 and Jayaram, 1999). For systematic analysis work of Jayaram (1999) has been referred.

\section{RESULTS AND DISCUSSION}

Fishes identified from Wajoo nullah, Kathua district, are given as below:

Superclass: Gnathostomata

Class: Actinopterygii

Sub class: Neopterygii

Division: Teleostei

Sub Division: Osteoglossomorpha

Order: Osteoglossiformes

Sub order: Notopteroidei

Family: Notopteridae

Genus Notopterus Lacepede

$L N$. notopterus (Pallas)

Genus : Chitala Fowler

2. C.chitala (Ham-Buch)

Sub division: Clupemorpha

Order: Clupeformes

Family: Clupeidae

Sub Family: Alosinae

Genus : Gudusia Fowler

3. G. chapra (Ham.-Buch.)

Sub division: Eutelostei

Super order: Ostariophysi

Order Cyprinifoimes

Family Cyprinidae

Sub family: Danioriinae (Rasborinae) 
Genus: Securicula Gunther 4. S.gora (Ham. -Buch) Genus: Salmostoma Swainson 5. S. bacaila (Ham.-Buch.) 6. S.punjabensis (Ham.-Buch.) Genus: Aspidoparia Heckel 7. Aspidopa morar (Ham.-Buch Genus: Barilius Ham.-Buch.

8. B.bendelisis (Ham.-Buch)

9. B.vagra vagra (Ham.-Buch)

10. B.modestus Day

Genus: Danio Ham. -Buch.', 11. D.devario (Ham.-Buch.) Genus : Esomus Swainson 12. E.danricus (Ham.-Buch.) Genus : Rasbora Bleeker 13. R.rasbora (Ham.-Buch.) Genus : Amblypharyngodon Bleeker 14. A.mola (Ham.-Buch) Genus : Chela Ham.-Buch. 15. C.laubuca(Ham.-Buch) 16. Ccachius (Ham-Buch) Sub Family: Cyprininae Genus : Cyprinus Linnaeus 17. C.carpio communis Linnaeus Genus : Tor Gray

18. T.tor (Ham-Buch)

19. T.putitora (Ham.-Buch.)

Genus : Puntius Ham.-Buch.

20. P.ticto (Ham.-Buch)

21. P.sophore (Ham. Buch.)

22. P.sarana, sarana (Ham.Buch.)

23. P.conchonius (Ham.-Buch.)

Genus: Labeo Cuvier

24. L.bata (Ham.-Buch.)

25. L.dero(Ham.-Buch.)

26. L.dyocheilus dyocheilus (Mc Cli)

27. L.gonius (Ham-Buch)

28. L.calbasu (Ham.-Buch.)

29. L.pangusia (Ham.-Buch)

30. L.boggut (Sykes)

Genus: Cirrhinus Oken

31. C.mrigala (Ham-Buch)

32. C.reba (Ham.-Buch.)

Genus: Osteobrarma Heckel

33. O.cotio cotio (Ham.-Buch.)

Sub family: Garrinae

Genus: Crossocheilus Kuh1\& van Hasselt

34. C.latitus diplocheilus (Heckel)

Genus: Garra (Ham.-Buch)

35. G.gotyla gotyla Gray

36. G.lamta (Ham.Buch.)

Family: Balitoridae

Sub family: Nemachelinae

Genus: Acanthocobitis Peter

37. A botia (Ham.- Buch)

Family: Cobitidae

Sub Family: Botinae

Genus: Botia Gray
38. B.almorhae Gray

39. B. lohachata Chaudhuri

Sub family: Cobitinae

Genus: Lepidocephalus Breker

40. L.guntea (Ham.-Buch.)

Order: Siluriformes

Family: Bagridae

Sub family: Ritinae

Genus: Rita Bleeker

41. R.rita (Ham.Buch.)

Sub family: Bagrinal

Genus: Mystus Scopoli

42. M.vittatus (Bloch)

43. M.bleekeri (Day)

44. M.cavasius (Ham.Buch.)

Genus: Aorichthys Wu

45. A.seenghala (Sykes)

Family: Siluridae

Genus: Ompok Lacepede

46. O.pabda (Ham.-Buch.)

Genus: Wallago Bleeker

47. W.attu (Bloch and Schneider)

Family: Schilbidae

Sub family: Schilbeinae

Genus: Pseudeutropius Bleeker

48. P.atherinoides (Bloch and Schneider)

Famiy:Amblycptidae

Genus: Amblyceps Blyth

49 A. mangois (Ham.-Buch.)

Family: Sisoridae

Genus: Bagarius Bleeker

50. B. bagarius (Ham.-Buch.)

Genus: Gagata Bleeker

51. G. cenia (Ham.-Buch.)

Family: Heteropneustidae

Genus : Heteropneustes Muller

52. H.fossilis (Bloch)

Super order: Accantloptergygii

Order: Beloniformes

Family: Belonidae

Genus: Xenontodon Regan

53. X. cancila (Ham.-Buch.)

Order: Perciformes

Sub order: Percoidei

Family: Chandidae

Genus : Chanda Ham.-Buch

54. C. nama Ham.-Buch

Genus: Parambassis Bleeker

55. P.ranga (Ham.- Buch

56. P.baculis Ham.-Buch

Family: Nandidae

Sub Family: Nandinae

Genus: Nandus Val.

57. N. nandus Ham.-Buch

Sub family: Gobinae

Genus: Glossogobius Gill:

58. G.giuris (Ham.-Buch)

Suborder: Channodei

Family: Channidae 
Genus : Channa Scopoli

59. C.punctantus (Bloch)

60. C.orientials Bloch and Schn

61. C.marulius (Ham.-Buch.)

62. C.striatus (Buch)

Order Synbranchiformes

Suborder Mastacembeloidei

Family Mastamcembelidae

Subfamily Mastacembelinae

Genus : Macroganthus Lacepede

63. M. pancalus Hamilton-Buchanan

Genus : Mastacembelus Scopoli

64. M. armatus (Lac.)

Fish fauna of Wajoo nullah, comprising of sixty four species, is more diversified in comparison to the other tributaries of the river Ravi. Joshi et al. (1978) enlisted 12 fish species belonging to 4 orders, 6 families and 11 genera from Kathua Khad and three fish species viz Barilius vagra, Tor putitora and Channa gachua from UJh river. Dutta et. al. (2006) noticed 27 fishes species belonging to 4 orders, 8 families and 20 genera from UJh river: 16 species belonging to 2 orders, 4 families and 12 genera from Tarna nullah and total absence of fish from Kathua Khad. Rathore and Dutta (2015) noticed 42 fish species belonging to 5 orders, 10 families and 27 genera from river UJh.

Dutta et.al, (2001) reported 59 fish species belonging to 6 orders, 15 families and 25 genera from river Basantar; an important tributary of the river Ravi, in Samba area. Sharma and Dutta (2012) resurveyed fish fauna of river Basantar and noticed 35 fish species belonging to5 orders, 10 families and 25 genera.

A rich fish diversity in Wajoo nullah in comparison to some other tributaries of the river Ravi is attributed to:

1. Perennial water flow and presence of large number of pools along its length

2. A rich macrophytic and algal diversity and density and other fish food organisms.

3. Migration of fish from the river Ravi for feeding and breeding. Presence of Bagarius, Tor, Labeo, Garra, Cirrhinus etc. in this nullah indicates fish migration from the river Ravi.

Fish conservation in this highly productive tributary of the river Ravi and other water bodies in Jammu requires a strict monitoring by the state fishery department. There is no check on fish size collection by fishermen. These collect fishes measuring few centimeters and weighing few gms. Commercial fishes like Tor tor, Tor putitora, Labeo spp, Cirrhinus spp, Aorichthys spp, Bagarius spp., etc weighing less than $100 \mathrm{gm}$ are collected by fishermen. There should be total ban on fishing during fish breeding season viz; May-August as is instructed in the licences issued by the state fishery department. Many states in our country are strictly implementing total ban on fishing during monsoon.

\section{Conclusion}

Present fish survey in Wajoo nullah has shown rich diversity of 64 species in comparison to some other tributaries of the river Ravi in Kathua district. This is a tributary to perennial water flow, rich diversity and density of fish food organism and fish migration from the river Ravi. Fish conservation requires monitoring by the state Fishery Department to check illegal fishing methods, fishing of small sized fishes and implementing total ban on fishing during monsoon.

\section{ACKNOWLEDGMENTS}

Emeritus fellowship awarded by UGC, New Delhi, is gratefully acknowledged. Mr. Pawan Paul Sharma, Assistant Director, Sate Fishery Department is acknowledge for providing information about Wajoo nullah. I express my thanks to the Head, Department of Environmental Sciences, University of Jammu, for providing necessary facilities in the department.

\section{REFERENCES}

Day, F. (1994). The fishes of India, being a natural history of the fishes known to inhabit seas and fresh waters of India, Burma and Ceylon, Fourth India Reprint Vol I and II, Jagmandier Book Agency, New Delhi,

Dutta, S.P.S and Kour, H. (2006). Fish fauna of Kathua District, Jammu region. In proceedings National Seminar: New Trends in Fishery Development in India, Punjab University, Chandigarh Feb. 16-18:233-240.

Dutta, S.P.S. and Malhotra, Y.R. (1984). An upto date checklist and a key to the identification of fishes of Jammu, Jammu University Review (Sc) J, 2:65-92.

Dutta, S.P.S., Bali, J.P.S., Kour, H. and Sharma, L. (2001). Hydro biology of river Basantar, an important tributary of the river Ravi. J.Aquatic BioL, 16 (1-2):41

Dutta, S.P.S., Gupta, S.C., Rathore, V. and Sharma, A. (2006). Fish fauna of some tributaries of the river Ravi; District kathua, J\&K State, In: Trends in Biodiversity and Aquaculture. Edited by Wanganeo, A. and Langer, R.K. Daya Publishing House, New Delhi: 443-452.

Hamilton, B.F. (1822). An account of the fishes found in the river Ganga and its tributaries. Edinburg and London.

Jayaram, K.C. (1999). The Freshwater fishes of the Indian Region. Narendra Publishing House Delhi.

Joshi, C.S. Sehgal, K.L. and Sunder S. (1978). Observations on the fishery resources of hill streams of Jammu Province with special reference to maha haseer and other commercial important species. Indian J. Fish, 25 (1-2): 197-206

Misra, K.S. (1962). An aid to the identification of the common commercial fishes of India and Pakistan, Rec. Indian Mus., 57; 1-320.

Sharma, A. and Dutta, S.P.S. (2012). Present and past status of fish fauna of river Basantar, an important tributary of the river Ravi in Samba district, Jammu (J\&K State). J. Applied and Natural Resources, 4(1): 123-126.

Rathore, V. and Dutta, S.P.S. (2015a). Some new fish records of river UJh, an important tributary of the river R avi, Kathua district, Jammu region J\&K State. Sourvenir $10^{\text {th }} \mathrm{JK}$ Science Congress, March 14-16, 2015, organized by University of Jammu: 163 (Abstract EVS 016).

Rathore, V. and Dutta, S.P. (2015b). Fish fauna of river UJh, an important tributary of the river ravi, District Kathua, Jammu. Env. Conservation J, 16(1-L 2): 81-86.

Talwar, P.K. and Jhingran, A.G. (1991). Inland Fishes of India and adjacent countries, Oxford and IBH publishing Co Pvt, Ltd. New Delhi Vol1 and II. 